\title{
Efektifitas Edukasi Tentang Jajanan Sehat Terhadap Peningkatan Pengetahuan dan Sikap Siswa Overweight
}

\author{
Firnaliza Rizona $^{a}$, Karolin Adhisty ${ }^{a}$, Fuji Rahmawatia ${ }^{a}$, Tri Candraca Firman ${ }^{a}$
}

aProgram Studi Ilmu Keperawatan Fakultas Kedokteran Universitas Sriwijaya, Jln. Raya

Palembang- Prabumulih KM. 32 Indralaya, OI, Sumatera Selatan, 30662, Indonesia

e-mail korespondensi : firnalizarizona@gmail.com

\begin{abstract}
Overweight on children can result an obesity. Obesity on children have become a global problem which should be handled immediately. One of the precipitation of overweight is food intake that is unhealthy snacking. One of the method for increasing the number of knowledge and attitude about healtyh snack on school aged children is health education. Peer could influencing the children habit in consuming snacking, so that group discussion can give impact on health education process. This research aim was to know the efektivity of education through Focus group discussion (FGD) to overweight children's knowledge and attitude about healthy snacking. This research was used approach of quasi experiment with one group pre-posttest design. The number of respondent was 50 overweight student divided become five group. Sample election used purposive sampling and FGD process conducted twice meeting. Data collected by using quessioner on pretest and posttest. Based on the result's data, there were increasing mean number of knowledge from 14.78 become 17.00 and mean number of attitude from 11.72 become 13.22. The statistic result with Wilcoxon test showed that there were effectiveness of education with the differences of knowledge value and attitude value pre and post FGD with $p$ value =0,000. Education concerning healthy snacking with group discussion can improve the value of knowledge and attitude school aged children with overweight for comprehending about healthy snacking. For school in order to inform about healthy snack on learning process with discussion which involve being active of children or by another media such as poster or leaflet.
\end{abstract}

Keywords : attitude, education, healthy snacking, knowledge, overweight.

\begin{abstract}
Abstrak
Overweight pada anak dapat mengakibatkan obesitas. Obesitas pada anak telah menjadi masalah global yang harus ditangani segera. Salah satu faktor pencetus kelebihan berat badan adalah asupan makanan yaitu jajanan tidak sehat. Salah satu metode untuk meningkatkan nilai pengetahuan dan sikap tentang jajanan sehat pada anak sekolah yaitu pendidikan kesehatan. Teman sebaya mampu mempengaruhi kebiasaan anak dalam mengkonsumsi jajanan, sehingga diskusi kelompok dapat memberikan dampak saat proses pendidikan kesehatan. Penelitian ini bertujuan untuk mengetahui efektifitas edukasi melalui Focus group discussion (FGD) terhadap peningkatan pengetahuan dan sikap anak overweight tentang jajanan sehat. Penelitian ini menggunakan pendekatan quasi experiment dengan one grup pre-posttest design. Jumlah responden sebanyak 50 siswa overweight yang dibagi menjadi lima kelompok. Pemilihan sampel menggunakan purposive sampling dan pelaksanaan FGD dilakukan sebanyak dua kali pertemuan. Data dikumpulkan dengan menggunakan kuesioner pada pretest dan posttest. Berdasarkan data penelitian didapatkan peningkatan rata-rata nilai pengetahuan dari 14.78 menjadi 17.00 dan nilai rata-rata sikap dari 11.72 menjadi 13.22. Hasil uji statistik dengan uji Wilcoxon menunjukkan bahwa terdapat efektivitas edukasi dengan adanya perbedaan nilai pengetahuan dan sikap sebelum dengan sesudah dilakukan FGD dengan nilai p=0,000. Edukasi mengenai jajanan sehat dengan diskusi berkelompok dapat meningkatkan nilai pengetahuan dan sikap anak sekolah overweight untuk memahami tentang jajanan sehat. Pihak sekolah agar menginformasikan mengenai jajanan sehat baik dalam proses pembelajaran dalam bentuk diskusi yang melibatkan keaktifan anak-anak maupun penggunaan media lain seperti poster atau leaflet.
\end{abstract}

Kata Kunci: edukasi, jajanan sehat, overweight, pengetahuan, sikap

\section{PENDAHULUAN}

Data UNICEF menunjukkan angka obesitas pada anak di Indonesia pada peringkat ke 7 dengan jumlah sebesar 14\%. Bahkan pada tahun 2011 Indonesia berada pada peringkat 1 yaitu berjumlah 2.968.000 anak (UNICEF, 2013).
Beberapa penelitian menunjukkan bahwa angka kejadian kelebihan berat badan pada usia sekolah dan remaja terus meningkat dari tahun ke tahun. (National geographic, 2018)

Obesitas pada anak telah menjadi masalah global yang harus ditangani 
segera. Masa anak- anak adalah masa dimana terjadi pertumbuhan dan perkembangan yang pesat sehingga terjadinya overweight dan obesitas pada anak jika tidak diatasi akan berperan dalam meningkatnya berbagai faktor risiko sehingga terjadinya bermacam penyakit metabolik seperti diabetes melituss, penyakit degeneratif, dan penyakit kardiovaskular. Penyebab obesitas antara lain faktor lingkungan, genetik, asupan energi yang meningkat, gaya hidup seharihari, aktifitas fisik dan perubahan struktur dinamis keluarga (Hasdianah, Siyoto, \& Paristyowati, 2014). Salah satu faktor terjadinya kelebihan berat badan adalah ketidak seimbangan asupan makanan. Saat ini konsumsi pada makanan yang mengandung pemanis buatan dan makan cepat saji erat hubungannya dengan kejadian obesitas. Jenis makanan junkfood seperti permen, kudapan yang mengandung penyedap rasa, teh, kopi dan makanan siap saji lainnya sering dikonsumsi oleh masyarakat (Caro, J. Ng, Taillie, \& Popkin, 2017). Dewasa ini, beberapa jenis junkfood sangat banyak ditemukan tidak jauh dari sekolah bahkan terdapat dikantin sekolah tersebut. (Cutumisu, N et al. 2017).

$$
\text { Sebuah hasil penelitian }
$$

menunjukkan bahwa konsumsi jajanan tidak sehat seperti minuman yang mengandung gula pada softdrink dan fast food dapat mengakibatkan kegemukan (Sahoo, K. Sahoo, B., Choudhury, A. Sofi, N, Kumar, R., \& Bhadoria, A. S, 2015). Oleh karena itu, penting untuk meningkatkan pemahaman anak sekolah agar mampu memilih jajanan yang mengandung nilai gizi seimbang dalam memenuhi kebutuhannya dalam bertumbuh dan berkembang. Selain pengetahuan, teman sebaya juga dapat mempengaruhi kebiasaan anak dalam mengkonsumsi jajanan. Kebiasaan teman sebaya dalam kelompok seperti figure idola, makanan, dan minuman mampu memberikan penerimaan yang sama pada teman-teman sebayanya. Begitu pula dengan pemilihan jajanan. Oleh karena itu, anak perlu mendapatkan informasi yang tepat mengenai jajanan yang baik untuk dikonsumsi dengan menciptakan lingkungan yang tepat.

Focus group discussion (FGD) merupakan salah satu metode yang mempunyai kelebihan dimana memberikan perspektif yang berbeda dibanding pengetahuan yang diperoleh dari komunikasi biasa seperti ceramah sehingga penyampaian dan penerimaan informasi bisa lebih secara mendalam, memperoleh informasi yang banyak secara cepat, mengidentifikasi dan menggali informasi mengenai kepercayaan, sikap dan perilaku kelompok tertentu, Menghasilkan ide-ide untuk penelitian lebih mendalam Irwanto (2013), serta keunutungan penggunaa FGD memungkinkan peneliti dan informan berdiskusi intensif dan tidak kaku dalam membahas isu- isu dan juga FGD mempunyai keuntungan dari yang metode yang lain FGD dilakukan sesuai karakteristik yang idealnya 7-11 orang sehingga memungkinkan setiap individu mendapatkan kesempatan mengeluarkan pendapat yang sama serta lebih leluasa.

Hal ini dibuktikan dengan penelitian dari Azza dan Susilo (2016) di pondok Miftahul Hasan Gunung Sepikul Paku Sari Kabupaten Jember kepada 50 remaja putri mengunakan pendekatan kuantitatif dan hasilnya adanya peningkatan pengetahuan yang signifikan, begitupun dengan penelitian yang dilakukan oleh Susilo (2017) yang berjudul pengaruh Focus group discussion Tentang Kesehatan Reproduksi Terhadap Persepsi Seks Bebas Remaja di Kelas X SMKN Kebonagung Kabupaten Pacitan hasil penelitian tersebut FGD efektif untuk meningkatkan persepsi siswa tentang Kesehatan Reproduksi Terhadap Persepsi Seks Bebas Remaja.

Menurut data Dinas kesehatan Kota Palembang tahun 2013 bahwa kecamatan Sukarame adalah kecamatan dengan angka penderita gizi berlebih terbesar di Kota Palembang yaitu sebesar 22.018 orang. 
Pada tahun 2015 angka kegemukan sedikit menurun di Kecamatan ini namun masih menunjukkan angka yang cukup tinggi di ketiga wilayah kerja puskesmasnya yaitu Puskesmas Sukarami, talang Betutu, dan Sosial. (Dinkes Kota Palembang, 2015).

Berdasarkan observasi awal yang dilakukan di salah satu Sekolah Dasar (SD) yang ada di Kecamatan Sukarame didapatkan bahwa hampir seluruhnya makanan yang dijajakan di kantin sekolah berupa makanan junkfood. Hasil wawancara yang dilakukan dengan beberapa orang siswa SD (sekolah dasar) menyampaikan bahwa anak sering jajan makanan seperti mie goreng, empekempek, sosis goreng, gorengan, bakso goring/bakar, minuman manis dan permen. Anak mengatakan tidak mengetahui makanan mana yang bergizi ataupun tidak. Anak mengatakan sering mengkonsumsi makanan tersebut yaitu $>2$ kali sehari. Anak merasa jika rasa dan bentuk menarik adalah hal yang paling penting. Berdasarkan latar belakang diatas, maka peneliti tertarik untuk mengetahui efektivitas edukasi dengan FGD terhadap peningkatan pengetahuan dan sikap tentang jajanan sehat pada anak overweight di Kecamatan Sukarame. Hal ini juga sesuai dengan roadmap penelitian Fakultas Kedokteran Universitas Sriwijaya dengan salah satu tema risetnya yaitu Perbaikan Gizi Masyarakat (Gizi) menuju pencapaian gizi seimbang dan tumbuh kembang anak dalam rangka menjaga kualitas anak Indonesia.

\section{METODE}

Desain penelitian yang digunakan pada penelitian ini adalah Quasi experiment dengan rancangan one grup pretest postest design. Penelitian dilaksanakan pada dua Sekolah Dasar yang berada di kecamatan sukarami Palembang. Sekolah dasar yang dipilih adalah Sekolah Dasar yang memiliki angka overweight tertinggi.
Populasi penelitian ini adalah siswa Sekolah Dasar dengan status gizi overweight melalui penghitungan Z-Score. Pengambilan sampel menggunakan purposive sampling dengan jumlah sampel yang didapatkan 50 responden overweight. Pada penelitian ini terdapat variable bebas yaitu edukasi melalui diskusi kelompok terarah (FGD) tentang jajanan sehat dan variabel terikat yaitu pengetahuan dan sikap tentang jajanan sehat.

Awal Pelaksanaan penelitian adalah melakukan pengukuran tinggi badan dan berat badan anak untuk menentukan status gizi anak. Anak dengan status overweight dipilih menjadi subjek penelitian lalu dibagi menjadi lima kelompok dengan total subjek 50 responden. Proses penelitian dilakukan dengan 4 tahap yaitu pretest, pemberian edukasi melalui diskusi kelompok FGD sesi pertama, dilanjutkan FGD sesi ke 2 dengan jeda satu hari setelah FGD sesi pertama, dan terakhir posttest. Sebelum pelaksanaan posttest setiap kelompok akan menyimpulkan hasil diskusi akhir yang difasilitasi oleh fasilitator menggunakan media powerpoint untuk memastikan hasil diskusi mereka tentang jajanan sehat adalah tepat.

Analisis data dilakukan menggunakan uji statistik dengan analisis univariat dan analisis bivariat. Analisa univariat yang dilakukan pada tiap variabel dari hasil penelitian, yaitu untuk mengetahui gambaran pengetahuan dan sikap sebelum dan setelah dilakukan intervensi. Berdasarkan distribusi data yang diperoleh maka data diolah dengan uji statistik uji Wilcoxon. Analisis bivariat terhadap pengaruh pemberian intervensi berupa pendidikan kesehatan tentang jajanan sehat dengan FGD terhadap nilai pengetahuan dan sikap anak tentang jajanan sehat pada anak overweight menggunakan analisis bivariate dengan nilai $p<0.05$ yaitu $\mathrm{p}=0,000$ untuk perubahan nilai baik pengetahuan maupun sikap pre-posttest. 


\section{HASIL}

Tabel 1. Deskripsi Karakteristik

\section{Responden}

\begin{tabular}{ccc}
\hline Karateristik & $\begin{array}{c}\text { Total } \\
(\mathbf{n})\end{array}$ & $\begin{array}{c}\text { Persentase } \\
(\%)\end{array}$ \\
\hline Jenis & & \\
Kelamin & & \\
\hline Laki-laki & 31 & 62 \\
Perempuan & 19 & 38 \\
\hline Kelas & & \\
4 & 4 & 8 \\
5 & 17 & 34 \\
6 & 29 & 58 \\
\hline Usia & & \\
9 tahun & 1 & 2 \\
10 tahun & 20 & 40 \\
11 tahun & 28 & 56 \\
12 Tahun & 1 & 2 \\
\hline TOTAL & 50 & $100 \%$
\end{tabular}

Tabel 3. Gambaran Sikap Responden Sebelum dan Setelah dilakukan Intervensi

\begin{tabular}{lccc}
\hline Sikap & $\begin{array}{c}\text { Nilai Rata- } \\
\text { rata }\end{array}$ & $\begin{array}{l}\text { Nilai } \\
\text { Minim } \\
\text { um }\end{array}$ & $\begin{array}{l}\text { Nilai } \\
\text { Maksim } \\
\text { um }\end{array}$ \\
\hline $\begin{array}{l}\text { Sebelum } \\
\text { (Pre Test) }\end{array}$ & 11.72 & $\mathbf{6}$ & 15 \\
$\begin{array}{l}\text { Setelah (Post } \\
\text { Test) }\end{array}$ & 13.22 & 9 & 15 \\
\hline
\end{tabular}

Tabel 3. menunjukkan bahwa nilai rata-rata (mean) sikap sebelum intervensi

Tabel 1. Menunjukkan bahwa karakteristik subjek mayoritas yaitu sebanyak $62 \%$ responden berjenis kelamin laki-laki. Pada karakteristik usia, mayoritas responden adalah berusia 11 tahun sebanyak 56\% responden. Jumlah responden terbanyak adalah yang berasal dari kelas VI (enam) Sekolah Dasar sebanyak $58 \%$ responden.

Tabel 2. Gambaran Pengetahuan Responden Sebelum dan Setelah dilakukan Intervensi

Tabel 2. menunjukkan bahwa nilai rata-rata (mean) pengetahuan sebelum intervensi adalah 14.78 dan setalah dilakuan intervensi meningkat menjadi 17.00 selain itu nilai pengetahuan minimal sebelum intervensi adalah 7 dan setelah intervensi meningkat menjadi 10.

\begin{tabular}{lccc}
\hline $\begin{array}{l}\text { Pengeta- } \\
\text { huan }\end{array}$ & $\begin{array}{c}\text { Nilai Rata- } \\
\text { rata }\end{array}$ & $\begin{array}{l}\text { Nilai } \\
\text { Minim } \\
\text { um }\end{array}$ & $\begin{array}{l}\text { Nilai } \\
\text { Maksim } \\
\text { um }\end{array}$ \\
\hline $\begin{array}{l}\text { Sebelum } \\
\text { (Pre Test) }\end{array}$ & 14.78 & 7 & 19 \\
$\begin{array}{l}\text { Setelah (Post } \\
\text { Test) }\end{array}$ & 17.00 & 10 & 20 \\
\hline
\end{tabular}
adalah 11.72 dan setalah dilakuan intervensi meningkat menjadi 13.22 selain itu nilai sikap minimal sebelum intervensi adalah 6 dan setelah intervensi meningkat menjadi 9.

Tabel 4. Pengaruh pendidikan kesehatan terhadap peningkatan pengetahuan

\begin{tabular}{cccccc}
\hline $\begin{array}{l}\text { Penge- } \\
\text { tahuan }\end{array}$ & $\begin{array}{c}\text { Pre } \\
\text { Test }\end{array}$ & Post Test & $\begin{array}{c}\text { Positive } \\
\text { ranks }\end{array}$ & Ties & $\begin{array}{c}P \\
\text { value }\end{array}$ \\
\hline Rerata & 14.78 & 17.00 & 39 & 11 & 0,000 \\
\hline
\end{tabular}

Tabel 4. menunjukkan bahwa hasil analisis dengan menggunakan Uji Wilcoxon didapatkan rata-rata nilai pengetahuan siswa pada saat setelah dilakuan intervensi mengalami peningkatan. Selain itu didapatkan nilai $\mathrm{p}<0.05$ yang menunjukkan adanya perbedaan nilai saat sebelum dan sesudah intervensi.

Tabel 5. Pengaruh pendidikan kesehatan terhadap peningkatan sikap

\begin{tabular}{cccccc}
\hline Sikap & $\begin{array}{c}\text { Pre } \\
\text { Test }\end{array}$ & $\begin{array}{c}\text { Post } \\
\text { Test }\end{array}$ & $\begin{array}{c}\text { Positive } \\
\text { ranks }\end{array}$ & Ties & P value \\
\hline Rerata & 11.72 & 13.22 & 38 & 12 & 0,000 \\
& & & & & \\
\hline
\end{tabular}


Tabel 5. menunjukkan bahwa hasil analisis dengan menggunakan Uji Wilcoxon didapatkan rata-rata nilai sikap siswa pada saat setelah dilakuan intervensi mengalami peningkatan. Selain itu didapatkan nilai $\mathrm{p}<0.05$ yang menunjukkan adanya perbedaan nilai saat sebelum dan sesudah intervensi dan terdapat 38 responden yang mengalami peningkatan nilai.

Tabel 6. Analisis pertanyaan pengetahuan

\begin{tabular}{|c|c|c|c|c|c|}
\hline \multirow[b]{2}{*}{ No } & \multirow[b]{2}{*}{ Pertanyaan } & \multicolumn{2}{|c|}{ Pre test } & \multicolumn{2}{|c|}{ Post test } \\
\hline & & Benar & Salah & Benar & Salah \\
\hline 1 & $\begin{array}{l}\text { Gorengan tidak mengakibatkan resiko } \\
\text { terjadi obesitas jika dikonsumsi secara } \\
\text { berlebih }\end{array}$ & 38 & 12 & 39 & 11 \\
\hline 2 & $\begin{array}{l}\text { Makanan yang dipilih untuk jajanan } \\
\text { adalah makanan yang mengandung gizi } \\
\text { seimbang }\end{array}$ & 39 & 11 & 41 & 9 \\
\hline 3 & $\begin{array}{l}\text { Jajanan yang mengandung banyak } \\
\text { minyak seperti gorengan adalah pilihan } \\
\text { baik untuk dikonsumsi saat jajan di } \\
\text { sekolah. }\end{array}$ & 44 & 6 & 45 & 5 \\
\hline 4 & 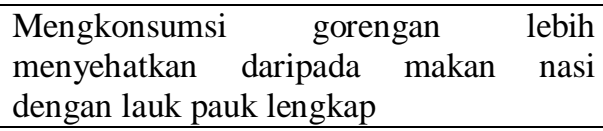 & 40 & 10 & 44 & 6 \\
\hline 5 & $\begin{array}{l}\text { Makanan jajanan yang penting rasanya } \\
\text { enak dan mengenyangkan walaupun tidak } \\
\text { tahu kandungan gizinya. }\end{array}$ & 38 & 12 & 46 & 4 \\
\hline 6 & $\begin{array}{lll}\text { Terlalu sering jajan makanan } & \text { yang } \\
\text { digoreng dapat berdampak } & \text { pada } \\
\text { penumpukan lemak dalam tubuh } & \\
\end{array}$ & 30 & 20 & 41 & 9 \\
\hline 7 & $\begin{array}{lccc}\text { Jajanan gorengan } & \text { lebih } & \text { banyak } \\
\text { mengandung } & \text { serat } \\
\text { buahan } & & & \text { dibanding } \\
\text { buah- }\end{array}$ & 30 & 20 & 38 & 12 \\
\hline 8 & $\begin{array}{l}\text { Meminum jus buah lebih menyehatkan } \\
\text { daripada minum pop ice }\end{array}$ & 38 & 12 & 41 & 9 \\
\hline 9 & $\begin{array}{l}\text { Lebih memilih makanan jajanan dengan } \\
\text { harga murah dan rasa enak }\end{array}$ & 33 & 17 & 44 & 6 \\
\hline 10 & $\begin{array}{l}\text { Rasa makanan jajanan yang enak lebih } \\
\text { penting daripada kandungan gizinya }\end{array}$ & 39 & 11 & 43 & 7 \\
\hline 11 & $\begin{array}{l}\text { Gorengan merupakan contoh makanan } \\
\text { jajanan sumber lemak, karbohidrat, } \\
\text { protein, dan mineral. }\end{array}$ & 29 & 21 & 29 & 21 \\
\hline 12 & $\begin{array}{l}\text { Kue-kue manis tidak baik jika } \\
\text { dikonsumsi terlalu sering karena banyak } \\
\text { mengandung gula }\end{array}$ & 38 & 12 & 38 & 12 \\
\hline 13 & $\begin{array}{l}\text { Jus buah yang ditambahkan gula lebih } \\
\text { bergizi dan menyehatkan }\end{array}$ & 36 & 14 & 38 & 12 \\
\hline 14 & $\begin{array}{l}\text { Jenis minuman seperti teh kotak, sprite, } \\
\text { Fanta, the botol, dan lain-lain } \\
\text { merupakan contoh minuman yang } \\
\text { memiliki kandungan gula tinggi }\end{array}$ & 34 & 16 & 35 & 15 \\
\hline 15 & $\begin{array}{l}\text { Es buah dengan tambahan gula, sirup dan } \\
\text { susu lebih menyehatkan dan bergizi }\end{array}$ & 22 & 28 & 34 & 16 \\
\hline 16 & $\begin{array}{l}\text { Mie goreng dan bakso goreng dengan } \\
\text { saus merah merupakan contoh makanan } \\
\text { jajanan yang sehat, bergizi dan } \\
\text { mengenyangkan }\end{array}$ & 37 & 13 & 45 & 5 \\
\hline 17 & Makanan jajanan dipilih karena rasa yang & 43 & 7 & 44 & 6 \\
\hline
\end{tabular}


NERS: Jurnal Keperawatan, Volume 15, No. 1, Maret 2019, (Hal. 1-13)

\begin{tabular}{clcccc}
\hline \multicolumn{2}{c}{$\begin{array}{l}\text { enak, harga murah dan tampilan } \\
\text { berwarna-warni }\end{array}$} & & & & \\
\hline 18 & $\begin{array}{l}\text { Makanan jajanan tinggi kalori merupakan } \\
\text { makanan jajanan yang sehat dan bergizi }\end{array}$ & 26 & 24 & 30 & 20 \\
\hline 19 & $\begin{array}{l}\text { Memilih jajan buah-buahan segar karena } \\
\text { menyehatkan dan mengandung serat yang } \\
\text { dibutuhkan oleh tubuh }\end{array}$ & 44 & 6 & 45 & 5 \\
\hline 20 & $\begin{array}{l}\text { Memilih mengurangi makanan jajanan } \\
\text { yang tinggi gula dan karbohidrat untuk } \\
\text { mencegah kegemukan atau obesitas }\end{array}$ & 37 & 13 & 40 \\
\hline
\end{tabular}

\section{Tabel 7. Analisis pertanyaan sikap}

\begin{tabular}{|c|c|c|c|c|c|}
\hline \multirow[b]{2}{*}{ No } & \multirow[b]{2}{*}{ Pertanyaan } & \multicolumn{2}{|c|}{ Pre test } & \multicolumn{2}{|c|}{ Post Test } \\
\hline & & & Salah & Benar & Salah \\
\hline 1 & $\begin{array}{l}\text { Makanan jajanan yang dikonsumsi } \\
\text { sebaiknya tidak mengandung gula dan } \\
\text { pemanis buatan yang tinggi }\end{array}$ & 31 & 19 & 39 & 11 \\
\hline 2 & $\begin{array}{l}\text { Minuman yang menggunakan sakarin atau } \\
\text { pemanis buatan sebaiknya tidak diminum }\end{array}$ & 39 & 11 & 39 & 11 \\
\hline 3 & $\begin{array}{l}\text { Lebih baik jajan di sekolah daripada } \\
\text { membawa bekal dari rumah }\end{array}$ & 42 & 8 & 46 & 4 \\
\hline 4 & $\begin{array}{l}\text { Sebaiknya menghindari makanan jajanan } \\
\text { yang banyak mengandung gula dan pemanis } \\
\text { buatan }\end{array}$ & 40 & 10 & 41 & 9 \\
\hline 5 & $\begin{array}{l}\text { Sebaiknya membeli es buah yang } \\
\text { ditambahkan gula, susu, dan sirup untuk } \\
\text { menambah nilai gizi }\end{array}$ & 33 & 17 & 34 & 16 \\
\hline 6 & $\begin{array}{l}\text { Memilih makanan jajanan sebaiknya yang } \\
\text { mengandung serat seperti sayuran }\end{array}$ & 48 & 2 & 49 & 1 \\
\hline 7 & $\begin{array}{l}\text { Makanan cepat saji (Fast Food) seperti fried } \\
\text { chickhen, bakso tusuk, mie goreng, dan } \\
\text { Chiki sebaiknya sering dikonsumsi karena } \\
\text { mengandung tinggi energi }\end{array}$ & 32 & 18 & 34 & 16 \\
\hline 8 & $\begin{array}{l}\text { Sarapan pagi dengan menu yang lengkap } \\
\text { lebih baik daripada jajan gorengan atau } \\
\text { bakso goreng di sekolah }\end{array}$ & 38 & 12 & 40 & 10 \\
\hline 9 & $\begin{array}{l}\text { Makanan jajanan sebaiknya juga } \\
\text { mengutamakan kualitas gizinya }\end{array}$ & 40 & 10 & 42 & 8 \\
\hline 10 & $\begin{array}{l}\text { Sebaiknya kalau memilih makanan jajanan } \\
\text { yang mahal karena pasti bergizi }\end{array}$ & 26 & 24 & 34 & 16 \\
\hline 11 & $\begin{array}{l}\text { Sebaiknya memilih jajan di sekolah sebagai } \\
\text { makanan utama sehari-hari }\end{array}$ & 40 & 10 & 40 & 10 \\
\hline 12 & $\begin{array}{l}\text { Kalau makan jajan sebaiknya yang banyak } \\
\text { mengandung gula karena rasanya enak dan } \\
\text { manis }\end{array}$ & 39 & 11 & 40 & 10 \\
\hline 13 & $\begin{array}{l}\text { Sebaiknya memilih makanan jajanan yang } \\
\text { tidak banyak mengandung minyak dan } \\
\text { lemak }\end{array}$ & 40 & 10 & 48 & 2 \\
\hline
\end{tabular}




\begin{tabular}{clllll}
\hline 14 & $\begin{array}{l}\text { Makanan jajanan yang hanya mengandung } \\
\text { tinggi kalori dan lemak lebih menyehatkan }\end{array}$ & 39 & 11 & 42 & 8 \\
\hline 15 & $\begin{array}{l}\text { Sebaiknya mengurangi makanan jajanan } \\
\text { yang tinggi gula untuk mencegah } \\
\text { kegemukan atau obesitas }\end{array}$ & 41 & 9 & 43 & 7 \\
\hline
\end{tabular}

Berdasarkan Tabel. 6 dan tabel. 7 dapat terlihat analisis dari pertanyaan baik pengetahuan dan sikap. Terdapat peningkatan jumlah responden yang menjawab benar sebelum intervensi dan setelah intervensi. Akan tetapi, terdapat pertanyaan dimana jumlah responden yang menjawab benar berjumlah sama antara sebelum dan setelah diberikan intervensi baik pada pertanyaan pengetahuan maupun pertanyaan mengenai sikap dari responden tentang jajanan sehat.

\section{PEMBAHASAN}

\section{Gambaran overweight pada Anak Sekolah Dasar (SD) di Kecamatan Sukarami}

Hasil penelitian menunjukkan gambaran karakteristik responden yang merupakan anak sekolah dasar dengan status gizi overweight yaitu didominasi oleh anak laki-laki sebesar 31 responden (62\%). Beberapa penelitian menunjukkan bahwa kejadian overweight dan obesitas pada anak usia sekolah khususnya sekolah dasar lebih banyak dialami oleh anak laki-laki. Akan tetapi akan mengalami perbedaan saat usia dewasa dimana peremuan lebih banya menderita kelebihan berat badan (Rachmi \& Baur, 2017).

Hasil penelitian juga menunjukkan bahwa mayoritas responden adalah berada di kelas 6 yaitu sebanyak 29 $(58 \%)$ responden dan usia 11 tahun yaitu sebanyak $28(56 \%)$ responden. Pada usia ini, anak memiliki perkembangan untuk mampu memilih sendiri apa yang ia inginkan, pengaruh dari peer group cukup bermakna termasuk saat menentukan jajanan. Pada tahap ini anak sudah mulai membangun kelompok dengan teman sebaya dan menunjukkan pengaruh teman sebaya dalam kelompok dalam merubah sikap dan norma (McGuire, Rutland, \& Nesdale. 2015)

\section{Gambaran Pengetahuan responden sebelum dan setelah dilakukan intervensi}

Berdasarkan hasil kuesioner sebelum dilakukan intervensi dapat diketahui bahwa nilai rata-rata pengetahuan adalah 14.78 dimana nilai minimum adalah 7 dan nilai maksimum 19. Pertanyaan yang paling banyak salah dijawab oleh responden adalah mengenai jajanan es buah dengan tambahan gula, sirup dan susu yaitu tidak sampai setengah responden yang benar menjawab bahwa jajanan tersebut tidak sehat. Kebiasaan jajan makanan dan minuman yang berenergi tinggi namun kekurangan zat gizi lainnya menjadi salah satu faktor yang perlu mendapat perhatian, karena kelebihan energi memicu anak mengalarni kelebihan berat badan dan berpotensi menderita obesitas (Marhamah, Abzeni, \& Juwita, 2014).

Sebaliknya terdapat dua pertanyaan yang jumlah responden hampir seluruhnya menjawab benar yaitu mengenai jajanan buah-buahan adalah baik karena banyak mengandung serat serta jajanan gorengan yang banyak tidak menyehatkan. Anak-anak sudah mengetahui bahwa jajan banyak gorengan tidak baik bagi kesehatan. Namun tidak sedikit anak yang mengakui bahwa mereka masih sering mengkonsumsi gorengan walaupun gorengan tidak baik bagi kesehatan. Hal ini sejalan dengan penelitian yang menunjukkan masih rendahnya persentasi siswa yang mampu menjawab pertanyaan tentang bahaya jajan gorengan dan minuman dengan gula dan pemanis 
buatan yaitu sebesar 43\% (Achmadi, 2015).

Setalah dilakukan intervensi terlihat peningkatan nilai rata-rata pengetahuan yaitu menjadi 17 dan nilai minimum/maksimum pun meningkat menjadi 10 dan 20. Peningkatan ini dapat dilihat dari keaktifan responden selama proses diskusi mengenai jenis jajanan yang tidak baik dikonsumsi dan dampaknya bagi kesehatan terutama pada peningkatan berat badan. Sebuah penelitian juga menunjukkan adanya pengaruh pada sikap memilih jajanan anak usia sekolah setelah diberikan pendidikan kesehatan tentang jajanan sehat (Handayani, Rohmah, \& Hamid. 2015).

Hasil posttest menunjukkan peningkatan yang cukup besar pada tiga pertanyaan yaitu pernyataan yang menyatakan Terlalu sering jajan makanan yang digoreng dapat berdampak pada penumpukan lemak dalam tubuh, Lebih memilih makanan jajanan dengan harga murah dan rasa enak, dan Es buah dengan tambahan gula, sirup dan susu lebih menyehatkan dan bergizi. Pada tiga pernyataan ini terdapat peningkatan jumlah responden menjawab benar yang paling banyak dibanding pretest. Hal ini menunjukkan bahwa anak mulai memahami bahwa jajanan gorengan terlalu sering dapat menyebabkan kegemukan, tidak hanya itu responden mulai mngetahui bahwa saat jajan juga harus memperhatikan kandungan gizinya yang bukan hanya karena rasanya enak.

\section{Gambaran Sikap responden sebelum dan setelah dilakuan intervensi}

Berdasarkan hasil kuesioner sebelum dilakukan intervensi diketahui bahwa nilai rata-rata (mean) sikap adalah 11.72 dan setelah dilakuan intervensi meningkat menjadi 13.22. Nilai minimum sebelum dilakukan intervensi adalah 6 dan meningkat menjadi 9 setelah dilakukan intervensi. Sejalan dengan penelitian Handayani, Rohmah, dan Hamid (2015) bahwa terdapat pengaruh pada sikap dalam memilih jajanan pada anak usia sekolah setelah diberikan pendidikan kesehatan mengenai jajanan sehat pada siswa Sekolah Dasar (Handayani, Rohmah, \& Hamid. 2015). Selain itu Data ini didukung oleh adanya peningkatan skor nilai sikap dengan responden terbanyak yaitu sebelum dilakukan intervensi dengan jumlah responden terbanyak 8 responden berada di skor 14 dan 15, sedangkan setelah dilakukan intervensi menjadi jumlah responden terbanyak yaitu 19 responden pada skor 15 .

Hasil kuesioner sebelum dilakukan intervensi menunjukkan bahwa anak tidak memperhatikan kandungan pada jajanan yang mereka beli saat berbelanja. Selain itu sebagian besar anak juga menganggap makanan junk food seperti gorengan, bakso tusuk, mie goreng dan chiki baik untuk sering dikonsumsi karena mengandung tinggi energi. Padahal kandungan makanan tinggi lemak, gula dan garam, indeks glikemik serta rendah serat dari makanan dapat memacu keseimbangan energi positif sehingga meningkatkan risiko penambahan berat badan pada individu tersebut (Damapol, 2013).

Pemikiran anak yang masih kurang tepat mengenai jajanan sehat harus menjadi perhatian karena anak belum memahami bahwa jajanan yang banyak mengandung minyak, gula, dan bahan makanan kimia tidak baik bagi perkembangan kesehatan anak. Bahkan sebagian anak masih lebih memilih jajan gorengan atau bakso disekolah dibanding sarapan pagi dirumah. Berdasarkan hasil diskusi selama FGD beberapa anak mengaku tidak sempat sarapan di rumah karena tidak disediakan menu sarapan oleh orang tua. Sangat penting juga peran orang tua dirumah untuk menyediakan sarapan yang sehat untuk anak. Orang tua bertanggung jawab dalam pemberian makan pada anak adalah meliputi saat 
memilih dan menyiapkan makanan, menyusun waktu makan dan kudapan sesuai dengan jadwal, memastikan lingkungan anak ketika makan sehingga anak dapat focus saat makan, dan mengatur agar anak bertingkah laku yang sesuai saat makan. Peran orang tua melalui perilaku pemberian makan pada anaknya sangat penting dalam membentuk status gizi pada anak (Rizona \& Lusmilasari, 2017)

Setelah dilakukan intervensi berupa diskusi kelompok mengenai jajanan sehat, terdapat peningkatan jawaban yang benar pada setiap item pertanyaan dan peningkatan jumlah nilai pada setiap responden. Seluruh anak menjawab benar mengenai sayuran adalah makanan yang mengandung banyak serat, saat diskusi pada pertemuan kedua anak pun sepakat memiliki pandangan bahwa jenis sayuran seperti bayam, kangkung, sawi dan wortel adalah jenis sayuran yang baik untuk dikonsumsi. Penelitian Fatharanni dan Anggraini (2017) menunjukkan baahwa konsumsi brokoli atau sayuran hijau dapat menurunkan secara signifikan nilai kolesterol total dan LDL pada penderita obesitas.

\section{Pengaruh pendidikan kesehatan terhadap peningkatan pengetahuan} Focus group discussion (FGD) dilakukan dengan membagi reponden menjadi kelompok yang berjumlah 10 orang/kelompok. FGD dilaksanakan dengan dipimpin oleh moderator yang akan memberikan pertanyaan pembuka untuk memicu jawaban peserta terkait jajanan sehat seperti pandangan responden tentang pentingnya jajanan sehat dan dampak yang akan diakibatkan jika mengkonsumsi jajanan yang tidak sehat. Selama proses diskusi anak bertukar pengalaman tentang jajanan yang biasa mereka makan disekolah. Beberapa anak mengetahui bahwa jajanan yang mengandung gorengan dan minuman yang mengandung banyak gula bisa mengakibatkan kegemukan sebaliknya beberapa anak baru mengetahui bahwa jajanan minuman yang manis bisa beresiko membuat kelebihan berat badan.

Proses diskusi yang terjadi sembari difasilitasi oleh moderator membuat anak mendapatkan informasi baru dan memahami bahwa hal yang diketahui oleh mereka sebelumnya adalah tidak benar. Responden pun bersemangat untuk mengurangi dan menghentikan jajanan tidak sehat yang selama ini telah mereka konsumsi.

Berdasarkan hasil uji analisis bivariate terhadap data yang digunakan yaitu menggunakan uji Wilcoxon didapatkan nilai $\mathrm{p}<0.05$ untuk melihat efektivitas pengaruh intervensi terhadap peningkatan nilai pengetahuan responden. Hal ini menunjukkan adanya peningktan antara nilai pre test dan post test terhadap nilai pengetahuan anak dengan status gizi overweight setelah diberikan intervensi. Terdapatnya pengaruh edukasi melalui diskusi kelompok terfokus tentang jajanan sehat terhadap peningkatan nilai pengetahuan anak overweight ini menunjukkan bahwa pemberian pendidikan kesehatan melalui diskusi kelompok pada anak yang seusia/sebaya mampu meningkatkan pengetahuan anak khususnya tentang masalah kesehatan. Anak tampak semangat dan riang saat proses diskusi karena anak langsung menceritakan dan berbagi pengalaman mengenai keseharian anak terutama untuk jajanan yang mereka konsumsi.

Hasil post test menunjukkan bahwa terdapat 39 responden (78\%) anak yang mengalami peningkatan nilai pengetahuan sebelum intervensi dan setelah intervensi. Terdapat 11 responden (12\%) yang memiliki nilai sama antara pre test dan post test serta tidak terdapat responden yang mengalami penurunan nilai.

Pada penelitian ini FGD digunakan sebagai pendekatan yang diberikan pada responden untuk mendapatkan informasi mengenai jajanan sehat. Kelompok yang terdiri dari 10 responden ini diberikan pertanyaan awal tentang bagaimana gambaran jajanan sehat menurut mereka. 
Seluruh responden sepakat bahwa jajanan sehat adalah jajanan yang mengandung gizi seimbang. Namun pada awal diskusi tampak sebagian besar responden tidak mengetahui secara spesifik jenis makanan yang mengandung gizi seimbang. Mereka menyampaikan bahwa jajanan seperti mie goring dan es buah yang terasa sangat manis karena telah dicampur gula dan sirup adalah jajanan yang baik untuk dikonsumsi. Akan tetapi, beberapa responden yang lain mampu memberikan gambaran tentang bahaya dan kaitannya jenis makanan tersebut terhadap resiko kelebihan berat badan yang akan diderita.

Penyamaan persepsi diakhir sesi FGD kedua juga mampu memberikan pemahaman yang seragam pada semua anggota kelompok yaitu makna tentang jajanan sehat dan jenis makanan yang termasuk kategori jajanan sehat. Anak juga mampu membagikan pendapat yang juga data diterima oleh teman anggota kelompoknya tentang bagaimana jajanan yang tidak sehat dan memiliki gizi yang tidak seimbang mampu membuat terjadinya kegemukan. Pada proses FGD ini diharapkan pemahaman yang didapatkan dapat melekat pada ingatan anak dan dapat mengembangkan pengetahuan yang mereka tidak ketahui sebelumnya.

Proses diskusi yang melibatkan anak yang seusia memiliki dampak yang lebih efektif dalam menggali informasi dan berbagi tentang pengetahuan yang mereka miliki. Pada penelitian Ayaz \& Acil (2014) mendapatkan hasil bahwa nilai pre post test pada siswa menunjukkan nilai yang signifikan ( $p<0,05)$ lebih tinggi pada siswa yang bersekolah pada sekolah yang menerapkan pembelajaran dengan berkelompok dibanding sekolah yang menerapkan latihan pembelajaran biasa. Intervensi yang diberikan berupa pendidikan kesehatan dengan FGD ini diharapkan dapat menjadi salah satu alternatif untuk meningkatkan pengetahuan siswa overweight tentang jajanan yang baik untuk dikonsumsi, sehingga anak pun dapat menentukan jajanan yang sehat dan mampu saling memberi contoh untuk rekan-rekan disekolah.

Peran moderator juga sangat penting dalam jalannya penelitian untuk tetap memastikan proses pembahasan diskusi tetap pada topic yang menjadi tujuan penelitian. Moderator memastikan responden tidak terlarut pada konsep yang tidak tepat tanpa mempengaruhi dan mengarahkan secara langsung pendapat responden sesuai konsep yang ada melainkan responden sendiri yang berpikir untuk menganalisis tentang jajanan sehat dengan berbagai perumpamaan yang diberikan.

\section{Pengaruh pendidikan kesehatan terhadap peningkatan sikap}

Hasil penelitian dengan menggunakan analisis Uji Wilcoxon didapatkan rata-rata nilai sikap siswa pada saat sebelum dilakukan intervensi adalah sebesar 11.72 dan setelah dilakukan intervensi meningkat menjadi 13.22 saat post test. Selain itu didapatkan nilai $\mathrm{p}$ sebesar 0,000 yang menunjukkan adanya perbedaan nilai saat sebelum dan sesudah intervensi sehingga terdapat pengaruh intervensi pada peningkatan sikap responden. Terdapat 38 responden yang mengalami peningkatan nilai sikap dan 12 yang memiliki skor yang sama dari sebelum intervensi serta tidak terdapat penurunan nilai pada responden stelah intervensi.

Peningkatan nilai pengetahuan pada responden pada penelitian ini diiringi dengan peingkatan nilai sikap. Hal ini sejalan dengan penelitian yang menunjukkan adanya peningkatan antara nilai pengetahuan dan nilai sikap pada seseorang yang telah diberikan edukasi. Penelitian yang dilakukan di Cangkringan Yogyakarta menunjukkan adanya peningkatan nilai pengetahuan dan sikap setelah dilakukan pembelajaran yang menyenangkan tentang jajanan sehat (Wijayanti, 2017). 
Diskusi kelompok terfokus (FGD) memiliki manfaat agar mampu lebih memberikan memori jangka panjang pada anak dibanding hanya edukasi melalui ceramah. Data yang diperoleh melalui FGD lebih kaya atau lebih informatif dibanding dengan data yang diperoleh dengan metode-metode pengumpulan data lainnya. Tujuan utama model ini adalah untuk meningkatkan keterampilan pemecahan masalah kolaboratif, keterampilan proses sains, dan kepercayaan diri siswa. Pada model ini siswa dituntut pro aktif dan memiliki ketergantungan positif yang tinggi dalam aktivitas tim pemecahan masalah kolaboratif untuk meningkatkan kepercayaan diri (Prahani, Nur, Yuanita, \& Limatahu, 2017). Kondisi ini membuat informasi berupa pengalaman antara satu responden akan menjadi informasi lainnya bagi responden yang lainnya. Pada usia anak sekolah, peran teman sebaya juga menjadi faktor penting yang dapat memperngaruhi anak dalam pengambilan keputusan.

Berdasarkan proses diskusi melalui FGD anak tampak memberikan motivasi pada anggota kelompok yang lain saat menceritakan pengalamannya dalam membeli jajanan disekolah. Responden yang terbiasa memilih jajanan yang lebih bersih dan tidak banyak mengandung minyak dan gula berlebih menyampaikan pertimbangannya mengapa memilih jajanan tersebut dibanding jajanan yang memiliki kandungan minyak tiggi seperti gorengan ataupun jajanan yang banyak mengandung bahan pemanis berlebih seperti es atau chiki-chikian. Responden yang lain, yang awalnya menyatakan suka memakan goring-gorengan menjadi terpacu untuk mengurangi konsumsi jajanan gorengan.

Proses diskusi berkelompok memicu anak lebih terbuka dalam menyampaikan pendapatnya serta lebih mudah pula mendengarkan informasi yang disampaikan oleh rekan-rekan mereka. Anak tampak antusias selama proses diskusi dan memiliki motivasi untuk merubah pola jajan mereka yang disampaikan pada akhir sesi diskusi. Focus Group Discussion merupakan diskusi kelompok kecil yang melibatkan peserta untuk menanggapi serangkaian pertanyaan yang terfokus pada satu topik (Prahani, Nur, Yuanita, \& Limatahu, 2017).

\section{SIMPULAN DAN SARAN}

Adanya efektivitas edukasi melalui Focus group discussion (FGD) terhadap peningkatan pengetahuan dan sikap mengenai jajanan sehat pada siswa overweight usia sekolah di Kecamatan Sukarami tahun 2018. Pada pihak sekolah diharapkan untuk dapat ikut serta dalam menginformasikan mengenai jajanan sehat baik dalam proses pembelajaran maupun penggunaan media lain seperti poster atau leaflet dan kepada peneliti lain dapat menggunakan FGD pada topik berbeda sebagai cara untuk meningkatkan pengetahuan dan sikap.

\section{UCAPAN TERIMA KASIH}

Terimakasih kepada tim peneliti yang telah membantu selama proses penelitian dan kepada Unit Penelitian dan Pengabdian Masyarakat Fakultas Kedokteran Universitas Sriwijaya atas bantuan pendanaan penelitian dengan Nomor : 088/UN9.1.4/UPPM/PL/2018

\section{DAFTAR PUSTAKA}

Achmadi, A D. (2015). Pengaruh Pendidikan Gizi dengan Media Buku Saku terhadap Peningkatan Pengetahuan dalam Pemilihan Jajan Anak SD Muhammadiyah 16 Surakarta. Publikasi Universitas Muhammadiyah Surakarta

Ayaz, S., Acil, D. (2014). Comparison of Peer Education and the Classic Training Method for School Aged Children Regarding Smoking and its Dangers. Journal of Pediatric Nursing. 30, e3-e12 
Azza, A., Susilo, C. (2016). Model Pembelajaran Reproduksi Sehat melalui Kelompok Sebaya Remaja Putri. Skripsi. FIK Muhammadiyah Jember

Caro, J. C., Ng, S. W., Taillie, L. S., \& Popkin, B. M. (2017). Designing a tax to discourage unhealthy food and beverage purchases: The case of Chile. Food Policy, 71, 86-100.

Cutumisu, N., Traoré, I., Paquette, M. C., Cazale, L., Camirand, H., Lalonde, B., \& Robitaille, E. (2017). Association between junk food consumption and fast-food outlet access near school among Quebec secondary-school children: findings from the Quebec Health Survey of High School Students (QHSHSS) 2010-11. Public health nutrition, 20(5), 927-937.

Damapol W, Mayulu N, Masi G. (2013).Hubungan konsumsi fast food dengan kejadian obesitas pada anak SD di kota Manado. E KP. 2013;1(1)

Dinkes Kota Palembang. (2015). Profil Kesehatan. Dinas kesehatan Kota Palembang.

Fatharanni, M. O., \& Anggraini, D. I. (2017). Efektivitas Brokoli (Brassica Oleracea var. Italica) dalam Menurunkan Kadar Kolesterol Total pada Penderita Obesitas. Jurnal Majority, 6(1), 64-70.

Handayani, D. Rohmah, N. Hamid, M A. (2015). Pengaruh Edukasi Peer Group Terhadap Sikap Memilih Jajanan Sehat Anak Usia Sekolah di SDN Kertosari 1 Jember. Universitas Jember.

Hasdianah., Siyoto S., Paristyowati Y. (2014). Pemenfaatan gizi, diet dan obesitas.Yogyakarta: Nuha Medika

Irwanto. (2013). Pendidikan Karakter. Bandung. Pusaka setia

Marhamah., Abzeni., Juwita. (2014). Perilaku Konsumsi dan Status Gizi Anak Sekolah Dasar di Kota Serang.
Jurnal Matematika, Sains, dan Teknologi, Volume 15.. Nomor 2, September 2014,97-105

McGuire, L., Rutland, A., \& Nesdale, D. (2015). Peer group norms and accountability moderate the effect of school norms on children's intergroup attitudes. Child Development, 86(4), 1290-1297.

National Geografic. (2018). Jumlah Obesitas Pada Anak-Anak dan Remaja Meningkat $10 \quad$ Kali Lipat. http://nationalgeographic.grid.id/keseh atan diakses tanggal 29 April 2018

Prahani, B. K., Nur, M., Yuanita, L., \& Limatahu, I. (2017). Validitas Model Pembelajaran Group Science Learning; Pembelajaran Inovatif di Indonesia. Vidya Karya, 31(1).

Rachmi, C.N., Baur, L.A. (2017). Overweight and obesity in Indonesia: prevalence and risk factors-a literature review. Public Health. Volume 147, June 2017, Pages 20-29

Rizona, F., \& Lusmilasari, L. (2017). Mother's feeding behaviours on overweight toddler. International Journal of Community Medicine and Public Health, 3(4), 831-836.

Sahoo, K., Sahoo, B., Choudhury, A. K., Sofi, N. Y., Kumar, R., \& Bhadoria, A. S. (2015). Childhood obesity: causes and consequences. Journal of family medicine and primary care, 4(2), 187.

Susilo, A. (2017). Pengaruh Focus Group Discussion Tentang Kesehatan Reproduksi Terhadap Persepsi Seks Bebas Remaja di Kelas X SMKN Kebonagung Kabupaten Pacitan. Skripsi. FIK Muhammadiyah Ponorogo.

UNICEF. (2013). Improving child nutritionthe achievable imperative for global progress.

Wijayanti, A.E, Lusmilasari L, Claramita, M. (2017). Promoting healthy food education for elementary school children at post Merapi eruption area 
NERS: Jurnal Keperawatan, Volume 15, No. 1, Maret 2019, (Hal. 1-13)

of Cangkringan district, Yogyakarta, Indonesia: A quasi experimental study using 'learning with fun' approach. Journal of Nursing Education and Practice. Vol. 7, No.

3. 